\title{
AN EXCEPTION TO COLLATERAL ESTOPPEL IN CRIMINAL CASES BECAUSE OF PROSECUTOR'S INCOMPETENCE?
}

One of the pervasive principles of the Anglo-American legal system is that litigation over the same issues should not go on endlessly. At some point, public policy demands that a decision be accepted as final and the parties be precluded from further dispute. In civil procedure this principle is embodied in the theories of res judicata and collateral estoppel; in criminal procedure it is embodied in the familiar theory of double jeopardy and the less familiar, but correlative concept of criminal collateral estoppel. ${ }^{1}$ Whereas double jeopardy prevents a single cause of action from being relitigated, criminal collateral estoppel prevents the relitigation of an issue and can span several causes of action so long as the issue is the same. In spite of the desirability of finality, application of this doctrine can cause flagrant injustice if the initial judgment has not been adequately litigated. Subsequent cases will multiply an already undesirable result when the parties are prevented from showing that the issue was incorrectly decided initially.

These consequences may be especially onerous if the inadequacies of the original determination were caused by the gross incompetence of the prosecutor. In Buatte v. United States, ${ }^{2}$ the Court of Appeals for the Ninth Circuit had to face this problem. The defendant allegedly had shot two American Indian children almost simultaneously, killing one and wounding the other. The United States ${ }^{3}$ was granted two separate indictments, one for murder and one for assault, but did not consolidate them for trial. The murder charge was tried first, the defendant's main defense being insanity. ${ }^{4}$ The accused was able to produce several expert witnesses who agreed that he had a "schizoid

1 "Res judicata" means that in civil actions the judgment in the first suit is conclusive in a second suit as to every question which was or might have been presented and determined in the first, if the parties and cause of action are the same. Double jeopardy applies only in criminal cases; the judgment in the first prosecution precludes any further prosecution for the same charge. Collateral estoppel applies in both civil actions and criminal actions: where the parties are the same in the two suits but the causes of action differ, the judgment in the first action estops relitigation of every question which was actually litigated and determined therein. See Gershenson, Res Judicata in Successive Criminal Prosecutions, 24 BRookry L L. REv. 12 (1957); Lugar, Criminal Lave, Double Jeopardy and Res Judicata, 39 Yowa L. REv. 317 (1954)'

2350 F.2d 389 (9th Cir. 1965), cert. denied, 385 U.S. 856 (1966).

3 Crimes against Indians are federal offenses. 18 U.S.C. $\$ 1152$ (1964).

4 Buatte v. United States, 330 F.2d 342, 343-45 (9th Cir. 1964). 
personality disorder" which caused him to drift in and out of reality, not knowing right from wrong during his psychotic state. This evidence was sufficient to shift to the prosecution the burden of demonstrating the defendant's sanity beyond a reasonable doubt. ${ }^{5}$ The government's single expert witness concluded only that the defendant "might well have known right from wrong." " Several lay witnesses testified that the defendant seemed perfectly normal one hour before and one hour after the incident, but no evidence was introduced concerning the typical length of similar psychotic states. No one witnessed the specific acts. At the close of the government's case, the defendant moved for a directed verdict of acquittal by reason of insanity. After this motion was denied, the jury brought in a "guilty" verdict upon which judgment was entered." On appeal, this conviction was reversed on the ground that the defendant's motion for a directed verdict should have been granted. ${ }^{8}$

When the government initiated the prosecution for the assault on the other child, the defendant sought to quash the information on the ground of former jeopardy, ${ }^{9}$ but the trial court denied the motion. ${ }^{10}$ At the trial, the government presented a much stronger case, ${ }^{11}$ using a second expert witness as well as more forceful testimony from the first expert. Both witnesses explicitly stated that the type of psychotic

5 "Some evidence" rebuts the presumption of sanity:

[W] hile it was true that every man is presumed to be sane, yet whenever by the testimony the question of insanity is raised then the fact of sanity, as any other essential fact in the case, must be established to the satisfaction of the jury beyond a reasonable doubt.

Davis v. United States, 165 U.S. 373, 378 (1897).

B 330 F.2d at 346 . The test of criminal responsibility was the M'Naughten test, i.e., did the defendant know right from wrong and that what he did was wrong.

7 Id. at 342 .

8 Id. at 347 .

9 Motion to Quash the Information, No. C-4785-Pct. (D. Ariz. Aug. 15, 1964).

10 Although a comprehensive study of double jeopardy principles is beyond the scope of this Comment, it seems probable that the double jeopardy claim will fail under either of the two standards now used by the courts. The older of the two, the "same evidence" test, dictates that "unless the first indictment were such as the prisoner might have been convicted upon by proof of the facts contained in the second indictment, and acquittal on the first indictment can be no bar to the second." Rex v. Vandercomb, 2 Leach 708, 720, 168 Eng. Rep. 455, 461 (1796). Clearly, the defendant could not have been convicted of the assault charge under the murder indictment since different people were involved. See State v. Hoag, 21 N.J. 496, 122 A.2d 628 (1956), aff'd, 356 U.S. 464 (1958). The more recent of the two standards, the "same transaction" test, dictates basically that the plea of double jeopardy will be sustained if the two offenses charged were part of the same criminal transaction. See State v. Greely, 30 N.J. Super. 180, 103 A.2d 639 (Hudson County Ct.), aff'd per curiam, 31 N.J. Super. 542, 107 A.2d 439 (Super. Ct. App. Div. 1954). Under this test, even the most liberal interpretation of "same transaction" would seem to lead to the conclusion that the incident involved two distinct acts against different persons and therefore, that two crimes had been committed and that the defendant had been in jeopardy for only one. See Curtis v. State, 22 Tex. Crim. 227, 3 S.W. 86 (1886). For a more complete discussion of former jeopardy, see Kirchheimer, The Act, the Offeruse and Double Jeopardy, 58 Y ALE L.J. 513 (1949).

11350 F.2d at 394. 
reaction alleged by the defendant lasts significantly longer than one hour, and that the defendant's leaving the scene of the crime and disposing of the murder weapon was so logical that he must have known right from wrong. Rigorous cross-examination of the defendant's experts helped to substantiate the latter point. ${ }^{12}$ The jury returned a "guilty" verdict and judgment was entered thereon. ${ }^{13}$ On appeal the defendant advanced the proposition that the prosecution should have been collaterally estopped by the first acquittal from relitigating the issue of his sanity. ${ }^{14}$ The court of appeals rejected the contention with the short equivocal statement: "In our opinion the concept of collateral estoppel has no application under the circumstances of this case." 15

The court's statement suggests three possible interpretations. First, the court may have meant that the theory of collateral estoppel does not apply to the specific facts of Buatte. ${ }^{16}$ This interpretation is unlikely. Like its civil counterpart, ${ }^{17}$ criminal collateral estoppel has three prerequisites: the issue must be one of fact, ${ }^{18}$ it must have been actually determined by the prior judgment, and it must have been

12 Id. at 393-94.

13 Id. at 393.

14 Buatte's attorney did not argue this issue in his brief. Since the issue was advanced only on oral argument, it is difficult to determine how forcefully the presentation was made. Nevertheless, the court of appeals was aware of the issue and undertook to decide it.

15350 F.2d at 394 n. 5 .

16 The court clearly could not have meant that collateral estoppel does not apply to criminal procedure, since the doctrine has been frequently recognized in the criminal area. Supreme Court acceptance was in answer to a contention that only former jeopardy protects the accused:

It cannot be that the safeguards of the person, so often and so rightly

mentioned with solemn reverence, are less than those that protect from a

liability in debt.

United States v. Oppenheimer, 242 U.S. 85, 87 (1916). It has been urged, albeit unsuccessfully, that collateral estoppel is a constitutional guarantee. See Hoag v. New Jersey, 356 U.S. 464, 471 (1958). The issue is far from dead. See People v. Rosota, 58 Cal. 2d 304, 327-29, 373 P.2d 867, 876-79, 23 Cal. Rptr. 779, 788-90 (1962); People v. Barnes, 240 Cal. App. 2d 428, 49 Cal. Rptr. 470 (Dist. Ct. App. 1966). Mayers \& Yarbrough, Bis Vexari: New Trials and Successive Prosecutions, 74 Harv. L. REv. 1, 39-41 (1960). "[S] hould some court irrationally reject the doctrine, it might well be that the constitutional argument would become extremely attractive to the United States Supreme Court." Vestal \& Coughenour, Preclusion/Res Judicata Variables: Criminal Prosecutions, 19 VAND. L. Rev. 683, 685 (1966).

17 The Restatement of Judgments defines civil collateral estoppel :

Where a question of fact essential to the judgment is actually litigated

and determined by a valid and final judgment, the determination is conclusive

between the parties in a subsequent action on a different cause of action . . . . RESTATEMENT, JUdGMENTS § 68(1) (1942).

18 Although collateral estoppel generally applies to all factual issues necessarily determined by a prior judgment, it is sometimes asserted that only ultimate facts, i.e., principle issues in the prior case, are deemed binding in the subsequent litigation. For a fuller discussion see Yates v. United States, 354 U.S. 298, 335-38 (1957); The Evergreens v. Nunan, 141 F.2d 927 (2d Cir. 1944); REstateMent, JudgMents \$ 68, comment p (1942) ; Note, Collateral Estoppel in Criminal Cases-A Supplement to the Double Jeopardy Protection, 21 Rutgers L. REv. 274, 278-81 (1967). 
essential to the prior judgment. ${ }^{19}$ All of these requirements are explicitly satisfied in Buatte. ${ }^{20}$

A second rationale for the court of appeals' refusal to apply collateral estoppel may be that the defendant waived the defense by his

19 Generally, in civil cases "mutuality is a prerequisite to the use of collateral estoppel : a prior judgment which would not bind one party as to questions of fact and of law cannot bind his adversary." See RESTATEMENT, JudganENTS \$ 68 (1942); Thornton, Mutuality in Res Judicata in New York, 23 BrookLYN L. REv. 267 (1957). However, this requirement is not applied in all criminal jurisdictions. The federal courts do not appear to recognize the doctrine:

Nor can there be any requirement of mutuality with respect to a criminal judgment's conclusiveness. An accused is constitutionally entitled to a trial de novo of the facts alleged and offered in support of each offense charged against him and to a jury's independent finding with respect thereto. But a "rule of evidence" has been recognized "which accords to the accused the right to claim finality with respect to a fact or group of facts previously determined in his favor upon a previous trial."

United States v. DeAngelo, 138 F.2d 466, 468 (3d Cir. 1943) ; accord, United States v. Carlisi, 32 F. Supp. 479 (E.D.N.Y. 1940).

Some state jurisdictions do permit the prosecution to bind a defendant with a previous judgment. See Commonwealth v. Evans, 101 Mass. 25 (1869) (prior conviction for felonious assault held to preclude proof of self-defense in a later manslaughter prosecution after victim died).

20 The solution to Buatte was hypothetically stated by Lugar, supra note 1, at 333 :

In an earlier prosecution for aggravated assault the accused pleaded only

"not guilty by reason of insanity" and instructions were given to the jury only on that theory of the case. The accused was found "not guilty by reason of insanity." Later the victim dies as a result of the wounds inflicted by the accused, and he is indicted for murder. This is a "different offense" from that in the first case. The defendant enters a plea of [criminal collateral estoppel] .... On these facts it seems clear that the second prosecution will not succeed. The issue of insanity at the time of the act has been determined.

In Buatte, although the jury implicitly found the defendant sane, the court of appeals held that no reasonable man could have so found beyond a reasonable doubt. A jury determination of sanity is the application of a legal standard to a factual situation. Although the definition of collateral estoppel classically includes only pure questions of fact, it is well established that determinations of fact dependent upon legal standards are equally conclusive.

[Collateral estoppel] does not apply to unmixed questions of law. Where, for example, a court in deciding a case has enunciated a rule of law, the parties in a subsequent action upon a different demand are not estopped from insisting that the law is otherwise, merely because the parties are the same in both cases. But a fact, question or right distinctly adjudged in the original action cannot be disputed in a subsequent action, even though the determination was reached upon an erroneous view or by an erroneous application of the law. That would be to affirm the principle in respect of the thing adjudged but, at the same time, deny it all efficacy by sustaining a challenge to the grounds upon which the judgment was based. . . A determination in respect of the status of an individual upon which his right to recover depends is as conclusive as a decision upon any other matter.

United States v. Moser, 266 U.S. 236, 242 (1924).

Nor can there be any question in Buatte that the issue of the defendant's sanity was litigated and determined, and was essential to the judgment. This is the major stumbling block to the application of collateral estoppel in most criminal cases since many factors not present in civil cases mitigate against a finding of necessary determination:

The generality of the plea usually employed in the first prosecution, in hopes of acquittal at that time, makes it impossible in most cases to determine what rights, questions, or facts were put in issue and decided in the former adjudication. The problem is accentuated by the multiple theories of acquittal generally offered in instructions and by the general verdict returned by the jury.

Lugar, supra note 1 , at 332-33. Therefore, the success of a collateral estoppel plea often depends on how carefully the prior record is searched to determine precisely 
failure to observe the procedural requirement of timely assertion at the trial court level. ${ }^{21}$ The government advanced this proposition in its brief to the Supreme Court opposing certiorari. ${ }^{22}$ However, the petitioner had contended, even before the second trial, that he was being placed in jeopardy a second time. ${ }^{23}$ There is authority holding that such a motion embodies the concept of collateral estoppel, preserving for appeal the argument that "his acquittal on the first charge was necessarily controlled by the determination of some particular issue or issues of fact which would preclude his conviction on the second charge." 24 At most, Buatte failed explicitly to spell out in his double jeopardy motion the exact basis of his reliance upon the prior determination of fact. The apparent intent of the defendant was to bring to the court's attention his acquittal on an issue that would preclude a second trial. To demand more in order to preserve the question for appeal, especially in the context of a doctrine as obscure as criminal collateral estoppel, is to "force resort to an arid ritual of meaningless form." 25

what was in issue. Compare Emich Motors Corp. v. General Motors Corp., 340 U.S. 558, 569 (1951) (a private anti-trust action relying on a criminal conviction) and Sealfon v. United States, 332 U.S. 575 (1948) with Hoag v. New Jersey, 356 U.S. 464, 473-77 (1958) (Warren, C.J., dissenting). See also Note, 21 RuTGERS L. REv. 274, 282-87 (1967).

Buatte's entire defense was founded upon the expert testimony of psychiatrists, and the directed verdict of acquittal was explicitly based on the failure of the prosecutor to carry the burden of establishing the defendant's sanity beyond a reasonable doubt. Thus, as the government was forced to concede in its brief in opposition to the petition for a writ of certiorari, the factual situation in Buatte does meet the general substantive requirements of collateral estoppel.

We recognized that that doctrine [collateral estoppel], under the decisions of this Court, applies in criminal as well as in civil cases. . . Moreover, there is no question that the issue of petitioner's sanity at the relevant time was before the court of appeals in the first case and that it was determined favorably to petitioner (although it had been determined adversely to him by the jury).

Brief for the United States in Opposition to the Granting of the Petition for a Writ of Certiorari, pp. 9-10.

21 See People v. Rodgers, 184 App. Div. 461, 464-65, 171 N.Y.S. 451, 453-54 (1918) (alternative holding), aff'd per curiam, 226 N.Y. 671, 123 N.E. 882 (1919) (collateral estoppel cannot be advanced for the first time on a motion to set aside a guilty verdict after conclusion of the trial).

22 Petitioner did not raise the claim of prior adjudication when the case was before the district court but raised it for the first time in the court of appeals. There is clear authority for the proposition that if the defendant does not raise the earlier adjudication of fact during the pendency of the proceedings in the trial court he may not thereafter insist on the benefit of proceedings in the triateral estoppel] on appeal.

Brief for the United States in Opposition to the Granting of the Petition for a Writ of Certiorari, p. 9. The authority cited by the government, however, referred to instances where the proponent of the claim had failed to make any relevant contention in the trial court. United States v. Bliss, 172 U.S. 321 (1899); Ferina v. United States, 340 F.2d 837 (8th Cir.), cert. denied, 381 U.S. 902 (1965); United States v. Hoyland, 264 F.2d 346 (7th Cir.), cert. denied, 361 U.S. 845 (1959) ; Bennett v. Commissioner, 113 F.2d 837 (5th Cir. 1940); Brady v. United States, 24 F.2d 399 (8th Cir. 1928).

23 See note 9 supra.

24 Harris v. State, 193 Ga. 109, 118, 17 S.E.2d 573, 579-80 (1941); see State v.

Greely, 30 N.J. Super. 180, 103 A.2d 639 (1954).

25 Staub v. City of Baxley, 355 U.S. 313, 320 (1958). 
A third possible interpretation of the Ninth Circuit's statement is that the court of appeals was properly exercising discretionary power in not applying collateral estoppel in this situation. The government's argument against the granting of certiorari was that:

[T] ] doctrine of collateral estoppel rests on considerations of policy and not upon constitutional command-essentially, the considerations which favor repose in litigation and the avoidance of needless harassment. We accordingly believe that there are circumstances in which its application may properly depend upon a reasoned exercise of discretion on the part of the courts. Petitioner's failure to raise the issue before the district court, combined with the evident absence of any purpose of harassment, furnishes justification, we believe, for the court of appeals' ruling that the fairness of the instant trial should be judged upon its own record. ${ }^{26}$

It has been argued above that the raising of the defense of double jeopardy at the trial level is all that should be required from a defendant urging collateral estoppel on appeal. ${ }^{27}$ If, therefore, an "absence of harassment" argument would be acceptable standing alone, Buatte may portend a significant development in the use of collateral estoppel in criminal procedure.

The meaning of the term "needless harassment" is not clear from the brief. Although the government contended that the second prosecution was not vexatious because two separate offenses were committed, ${ }^{28}$ it conceded that the issue of sanity, central to each crime, was litigated and determined at the first trial. ${ }^{29}$ Certainly the defendant was harassed to the extent that he was forced to conduct a full second trial which would have been obviated by the application of collateral estoppe1. ${ }^{30}$ Certainly the second trial was "needless" in the sense that

26 Brief for the United States in Opposition to the Granting of the Petition for a Writ of Certiorari, p. 10. (Emphasis added.)

27 See text accompanying notes 21-26 sipra.

28 The government contended:

This is not an instance in which a single act gave rise to multiple offenses slightly varied in the matter of their definition and in which the prosecution, having failed on one charge, seeks to try what is essentially the same offense under another heading. Petitioner committed two distinct crimes of violence against two persons, with grave consequences to each. There were two distinct harms or evils involved and one may venture with assurance that there is no system of law which would not view the two acts in question as wholly separate offenses.

Brief for the United States in Opposition to the Granting of the Petition for a Writ of Certiorari, pp. 9-10.

$29 I d$. at 10.

30 Ordinarily, the doctrine cannot prevent the second trial entirely. However, when as here the issue collaterally estopped is central to the second cause of action, the second trial will be eliminated. United States v. DeAngelo, 138 F.2d 466, 469 (3d Cir. 1943); United States v. Carlisi, 32 F. Supp. 479 (E.D.N.Y. 1940) ; Annot., 9 A.L.R.3d 203, 235 (1966). 
the issue of his sanity had already been determined. Therefore, it would seem that the term "needless harassment" means that the government was not trying to wear down the defendant in order to secure a conviction, but was simply seeking to obtain a just result by minimizing the effect of a questionable judgment. The doubt about the first judgment springs from the evident weakness of the government's case in response to the shifted burden of proof. Since the testimony presented in the second trial was apparently available for use at the first one, there seems to be no explanation for this infirmity other than the gross unpreparedness of the prosecutor. Thus, a suggested interpretation of the Ninth Circuit's holding might be that a court has discretion to deny a defendant's claim of collateral estoppel where the initial judgment is suspicious because the prosecuting attorney was grossly derelict in his duty. In such a situation, the second proceeding would not be considered "needless harassment" since society's interest in protecting itself against crime demands adequate representation before the issue can be foreclosed from litigation. This rationale would require a minimum degree of certainty before collateral estoppel can be invoked.

Such a theory is somewhat unusual in this context since the government had the opportunity to litigate the issue fully at the murder trial. In the closely analogous areas of double jeopardy and civil collateral estoppel, such a claim is unavailable. The doctrine of double jeopardy poses a complete bar to any state attempt to overturn an acquittal or even to challenge a sentence, given the most willful dereliction of duty by the prosecutor. ${ }^{31}$ It should be noted that the theory that society requires a minimal degree of certainty was rejected in the double jeopardy clause of the Fifth Amendment. In civil litigation the courts are also united in their opposition to an exception to collateral estoppel when a case has been inadequately prepared. $^{32}$

Nevertheless the double jeopardy and civil estoppel situations can be distinguished. First, unlike double jeopardy, the reach of collateral estoppel may extend over many different causes of action, amplifying the effects of the first inadequately prepared case. The advantage of

31 In State ex rel. Curtis v. Heflin, 19 Ala. App. 222, 96 So. 459 (1923), for example, the defendant was convicted of contributing to the delinquency of a minor and sentenced to twelve months at hard labor. While the appeal of the defendant was pending, a state solicitor convinced the appellate judge that the penalty should be reduced to a one hundred dollar fine. An attempt to set aside the fine on the ground that the solicitor had wrongfully influenced the judge was denied:

It is a full answer to such a contention (that the court was misled by the

solicitor's representations) that it is not alleged or shown that the defendant

had any part whatever in misleading the court; and surely he should not be

held responsible for the errors or faults of the attorney for the state who prosecuted him.

Id. at 226, 96 So. at 462-63.

32 See Tait v. Western Md. Ry., 289 U.S. 620, 625-26 (1933) ; Deposit Bank v. Board of Council, 191 U.S. 499, 510 (1903). 
discretionary denial of collateral estoppel is that it restricts the effects of such incompetence to a single cause of action. ${ }^{33}$

Second, civil collateral estoppel is distinguishable from criminal collateral estoppel on public policy grounds. Society's immediate interest in the certainty of the criminal law is significantly greater than its interest in the certainty of the civil law. The decision that one private party shall lose money to another private party despite his attorney's incompetence does not compel a similar decision that a criminal be set free to endanger the public. There is added pressure for initial accuracy in criminal trials since the state usually does not have the right of appeal to redress errors. ${ }^{34}$

Nevertheless, the undesirability of perpetuating erroneous judgments, as embodied in the principle of discretionary application of collateral estoppel, absent "needless harassment," must be balanced against the two basic needs for collateral estoppel in the criminal law : prevention of harassment and trial efficiency.

Modern penal codes, by classifying the same criminal act into a multitude of statutory offenses, amplify the potential for harassment as well as impede the efficiency of the criminal system. The protection against double jeopardy is too narrow to lessen these difficulties. ${ }^{35}$ Furthermore, unless the defendant consents, consolidation of charges by the government is often prevented by strict rules designed to prevent trial prejudice. ${ }^{36}$ Thus, when the accused exercises his right to a fair and dispassionate trial, he must be prepared for multiple litigation over the same set of circumstances. In this situation, collateral estoppel gives the accused the assurance that he will only have to litigate each issue once; he can therefore afford to throw all his resources into the initial conclusive determination. The use of collateral estoppel in this context also prevents the prosecution from using the first of several trials as a preview of the accused's defense. A defendant would be severely burdened if after defending himself once, he must present his case anew against an adversary with superior

33 It might be argued that since collateral estoppel is merely a rule of evidence and does not rise to a constitutional guarantee, courts may have somewhat more and doesibility in adapting its use to the needs of criminal procedure. See note 16 supra.

34 Mayers \& Yarbrough, supra note 16, at 33. Appeal is, of course, available to civil litigants and criminal defendants who feel their rights have been prejudiced by trial conduct. Furthermore, if a civil lawyer is guilty of severe neglect, he may be liable for malpractice, thereby compensating his client for money lost; no such compensatory action is available to the government or to society in a criminal situation.

35 See, e.g., State v. Hetler, 203 A.2d 69 (Del. Sup. Ct. 1964); Martinis v. Supreme Court, 15 N.Y.2d 240, 206 N.E.2d 165, 258 N.Y.S.2d 65 (1965).

36 Prejudice may be established in many ways, e.g., danger that the jury will not keep separate the proof offered for each crime, danger that the accused will be embarrassed in defending against two charges at the same trial and danger of the inflammatory nature of the principal crime. ORFIELD, CRIMIMAL ProCEDURE UNDER THE FEDERAL Rules $\$ 14: 69$ (1966); SHADOAN, LAw AND TACTICS IN FEDERAL CRIMINAL. CASES $180-83$ (1964). 
prestige, superior resources and, now, full knowledge of his entire case. $^{37}$

In Buatte the government apparently felt that these protections would not be endangered because there was an "absence of needless harassment." Even if this were true in Buatte, it would seem that such discretionary denial of estoppel as a principle of criminal procedure has great inherent potential for abuse. In view of the government's responsibilities and resources, it is offensive to allow the prosecutor to come into a second trial and use an assertion of his prior incompetence to the detriment of the defendant. Whether the poor performance in the first trial was inadvertent or deliberate, the effect of relitigation is the same on the defendant; in an endurance contest of successive trials, he is likely to be "worn down" even by a prosecutor with the most "honorable" intentions. This is the true meaning of harassment in the collateral estoppel context. ${ }^{38}$

Furthermore, the factual determination of a "failure of certainty" due to prosecutorial incompetence, in addition to the determination of "needless harassment," is difficult. If the principle of discretionary application of estoppel were to prevail, it would seem that the prosecution should at least be required to present the trial judge with affidavits of the "newly available" evidence. But, how much evidence is needed before it appears that there was an unacceptable "failure of certainty" at the first trial? Must the prosecution show a probability of guilt or merely a possibility of guilt? How is the inconvenience of the accused to be balanced against this need for certainty? In this situation, where one party is trying to prove its own incompetence, essential elements of adversary posture are absent. It would be all too easy for the prosecutor to claim routinely that a former acquittal resulted from prosecutorial incompetence, and hence a settled issue should be relitigated. What may have been a tactical decision not to present certain evidence at the first trial may be presented later as "nonharassing" error. The possibilities for disguised harassment are apparent.

There also is a danger that the availability of a "second chance" may encourage slipshod performance ${ }^{39}$ or the use of the first proceeding as a discovery device by the prosecutor. This is impermissible. If the state chooses to force an individual to defend his freedom, it should be prepared to prosecute him competently and to accept the

37 See Mayers \& Yarbrough, supra note 16, at 32. For an excellent discussion of the inequalities between these adversaries, see Goldstein, The State and the Accused: Balance of Advantage in Criminal Procedure, 69 Y ALE L.J. 1149 (1960).

38 The government proposal tends to look at collateral estoppel as an equitable estoppel, i.e., responding to the equities, or lack of same, in each case. See Spelker v. Hankin, 188 F.2d 35 (D.C. Cir. 1951). This, however, is contrary to the stricter basis for estoppel by judgment which admittedly may "indeed often operate very harshly" in a given case. Bennett v. Helvering, 137 F.2d 537 (2d Cir. 1943).

39 Lugar, supra note 1 , at 346. 
final determination of an issue. Thus collateral estoppel serves as a deterent against dereliction of duty by the state when an individual is subject to multiple charges.

Discretionary denial of collateral estoppel would increase the amount of litigation needed to dispose of a case. ${ }^{40}$ This doctrine would require hearings involving careful case-by-case analysis of subtleties not readily apparent from the record. Should estoppel eventually be denied, lengthy issues must be relitigated. Although the total amount of time needed to relitigate issues which do not receive adequate treatment might be small, discretionary denial might well become a favored weapon in the prosecutorial armory. Unless the standard is so strict that it is virtually impossible to meet, the government might be tempted to abuse the process either by not making a good-faith effort or by deliberately "lying-in-wait" for the second time around. In these circumstances, the amount of court time consumed by the hearing of motions and the relitigation of issues would be substantial. The danger of overclogged dockets, wasted public money, and diluted prosecution efforts on other pressing cases overshadow the danger that a given issue may have been incorrectly decided.

The only viable procedure in the criminal law for exceptions to the operation of collateral estoppel is group analysis of related types of situations. For example, many jurisdictions hold that an acquittal secured by the defendant's own statements cannot collaterally estop a subsequent perjury prosecution even if the defendant's credibility was directly in issue in the former proceeding. ${ }^{41}$ This exception recognizes the increased likelihood that defendants will perjure themselves if they are aware of their immunity from perjury prosecution. It has also been suggested that due to the high likelihood of inadequate preparation by both sides, a minor prosecution in some circumstances should not collaterally estop a subsequent prosecution for a major crime. ${ }^{42}$

40 The importance of this danger is disputed. Compare Knowlton, Criminal Law and Procedure, 11 Rutgers I. REv. 71, 94 (1956), with Mayers \& Yarbrough, supra note 16.

41 The most outspoken court taking this position claims to do so in the interests of public policy. See Jay v. State, 15 Ala. App. 255, 73 So. 137 (1916); accord, people v. Niles, 300 IIl. 458 , 133 N.E. 252 (1921). Contra, Ehrlich v. United States, 145 F.2d 693 (5th Cir. 1944). If the defendant lies, and as a result gains an acquittal, he will be shielded from possible punishment not only for the substantive crime (due to the operation of double jeopardy), but, if collateral estoppel applies, also from punishment for his prejury. See Gershenson, stpra note 1, at 20.

42 Assume that the defendant strikes a person and is tried and acquitted of a minor assault charge, his sole defense being insanity. He thereby avoids payment of a small fine. By a strange quirk of fate, fatal complications set in and the victim of a small fine. The defendant is then tried for murder or manslaughter. Assuming that all the requirements for collateral estoppel are met, the defendant should be acquitted without need of a second trial since the jury clearly accepted his defense in the assault trial. Nevertheless, the doctrine would probably not apply. See Comment, 27 Texas L. Rev. 231, 243 (1948). The danger is that mildness of the initial crime and its light penalty lulled the state into not forcefully prosecuting the case or spending money for necessary experts. See United States v. Stone \& Downer, 274 U.S. 225 (1927). This "minor-major" exception, however, is merely an acknowledgment of the importance of incentive in litigation, compensating for inadequate preparation where such 
This exception recognizes the likelihood of perfunctory performance when there is little incentive to litigate. Neither of these exceptions relies upon the particular merits of the case at hand, ${ }^{43}$ as would the exception suggested in Buatte. Instead, each represents a judgment by courts that application of collateral estoppel to most cases under such circumstances will create more overall injustice than if the exception is made. When the exception is made on a situational basis, the court does not have to make a detailed factual determination and the accused is afforded a standard rule upon which he can rely in judging his position. Decisions about prosecutorial incompetence cannot be made on the basis of group analysis.

Thus, although some applications of collateral estoppel may perpetuate shocking injustices, the balance of public policy weighs against the allowance of any discretionary exception for prosecutorial incompetence.

The principal objective of criminal procedure . . . like that of procedure generally, is to assure a just disposition of the dispute before the court. But because the time, resources and ability to determine what is just are limited, a procedural system inevitably represents a series of compromises. Justice to society is sometimes taken to require that a given case be used not only to deal with the situation immediately before the court but also to serve larger public interests . . . . The underlying premise is social utilitarianism. If the criminal goes free in order to serve a larger and more important end, then social justice is done, even if individual justice is not. ${ }^{44}$

incentive was lacking. The closest case in point is Martinis v. Supreme Court, 15 N.Y.2d 240,206 N.E.2d 165,258 N.Y.S.2d 65 (1965). In that case the defendant was acquitted of reckless driving and driving while intoxicated (both traffic code violations). He was then indicted for vehicular homicide (a Penal Code violation) and sought to stop proceedings by a writ of prohibition on the grounds of double jeopardy and criminal collateral estoppel. The court of appeals held that successive trials on charges of reckless driving and vehicular homicide did not place the defendant in double jeopardy. However, one concurring judge and the three dissenting judges felt that litigation of the issue of reckless driving was precluded by the previous acquittal. One commentator concluded:

Accepting the clear finding of the first trial in the second would be desirable, because it would tend to shorten litigation and because it would not require that an accused defend his innocence more than once. Of course, such an approach may also make final a fanlty determination, especially when, as in Martinis, the first trial was on a traffic charge before a court of limited jurisdiction.

79 HARV. L. Rev. 433, 435-36 (1965). (Emphasis added.)

It would seem Martinis should fall outside the minor-major exception since the death of the riders in the other car was known to the state and the second trial was foreseeable. Even if Martinis is within the minor-major exception, Buatte clearly is not since there were two indictments outstanding at the time of the first trial. There was no lack of incentive to litigate the initial prosecution diligently in such circumstances.

43 See Mayers \& Yarbrough, supra note 16, at 31.

44 Goldstein, supra note 37, at 1149. 
Collateral estoppel is such a compromise. In cases like Buatte, the price of that compromise may be freeing a dangerous criminal. Under such circumstances, however, the price of failure to maintain the compromise would be a severe strain on accused citizens and the values inherent in our system of criminal justice. 